\title{
The Italian Alpine and Subalpine Trouts. Taxonomy, Evolu- tion, and Conservation
}

\author{
Gianluca Polgar ${ }^{1, *}$, Mattia Iaia ${ }^{2}$, Tommaso Righi ${ }^{3}$, and Pietro Volta ${ }^{4}$
}

Water Research Institute (IRSA)-CNR, Largo Tonolli 50, 28922 Verbania Pallanza, VB, Italy; mattia.iaia@cnr.it (M.I.); tommaso.righi@cnr.it (T.R.); pietro.volta@cnr.it (P.V.)

* Correspondence: gianluca.polgar@cnr.it or gianluca.polgar@gmail.com

\begin{abstract}
Simple Summary: In a great part of the world, trout fishing has long inspired human spiritual ideals of immersion into nature and recreation, far removed from the fast-encroaching urbanization. Concurrently, these values and emotions fueled a white-heat business, establishing a florid market of outdoor recreation. Since the $20^{\text {th }}$ century, the trout-culture industry strived to provide anglers with fishing entertainment by stocking massive amounts of non-native trouts in dozens of countries, irrespective of the lakes' and rivers' carrying capacity. This had dire consequences on the structural and functional diversity of these ecosystems. 'Trout wars' sparked throughout the world between the promoters of stocking activities and the promoters of 'wild trout management' and ethics. The 'Italian trout war' has been fought on the harsh battleground of trout taxonomy, ecology, distribution, and native vs. non-native interfertile species. Northern Italy, home to the Italian Alpine and subalpine trouts and economic center of the national trout-culture and stocking industry, was particularly affected by this clash. We review here the state of art of this ongoing debate, outlining our scientific view of the taxonomy, evolution, distribution, and sustainable management of the native Italian trouts of northern Italy.
\end{abstract}

\begin{abstract}
During the last 150 years, the trout-culture industry focused on enhancing trout populations by stocking, in response to the growing anglers' demand and the habitat degradation associated to the rapid urbanization and hydropower development. The industrialized north of Italy, home to the Italian Alpine and subalpine trout populations, is the source of most of the revenues of the national trout-culture industry. Its rapid growth and the massive introduction of non-native interfertile trouts eroded the genetic diversity of native lineages, leading to harsh confrontations between scientists, institutions, and sportfishing associations. We review here the state of art of the taxonomy and distribution of the northern Italian native trouts, presenting both scientific results and historical documentation. We think the only native trouts in this region are Salmo marmoratus, widespread in this region, plus small and fragmented populations of $S$. ghigii, present only in the Southwestern Alps. We strongly recommend the interruption of stocking of domesticated interfertile non-native trouts in this area, and recommend the adoption of Evolutionary Significant Units for salmonid fishery management. We further propose future research directions for a sustainable approach to the conservation and ecosystem management of the fishery resources and inland waters of northern Italy.
\end{abstract}

Keywords: Recreational fisheries fishery management; introgressive hybridization; stocking; nonnative species; allochthonous species; trout fishing; trout taxonomy 


\section{Introduction: the global cultural value of trout and the 'trout wars'}

In Europe, freshwater angling originated as subsistence and small-scale artisanal fisheries serving local markets, growing alongside sportfishing as early as in the Late Middle Ages, virtually becoming a synonym of trout fishing [1-3]. Analogous subsistence trout-fishing cultures also developed in hunting and gatherer societies, such as the Native American cultures [4].

Sportfishing and trout fly fishing greatly expanded during the $19^{\text {th }}$ century, spreading throughout the world through European colonialism (America, Asia, Africa, Australia, New Zealand) and the rise of the nation-states, associating with cultural, economic, spiritual, and recreational values [3]. Artificial propagation was scientifically described and popularized in France in the 1840s-1850s. In the European imperialistic societies, highly interconnected by steamships and railroads, these propagation methods fueled a burgeoning outdoor recreation industry, i.e. the consumption of nature for leisure-class consumers [5]. This sporting culture gave rise to present-day fishery management and angling, making trout a globalized commodity through the introduction, acclimatization, and naturalization of non-native trout species provided by private and governmental associations. The European diaspora to other continents following World War I further accelerated this process. 'Salmonizing' became a synonym of acclimatization [6]. The first Italian hatchery was established in Piedmont in 1859 [7], and experiments of artificial propagation and acclimatization of non-native fishes, namely Coregonus and Salvelinus species from Switzerland and Germany, were conducted in several subalpine lakes during the 1860s-1890s [8]. Introductions and translocations accelerated with the establishment of the two Italian fishery centers in Brescia and Rome, in 1893-1895, with jurisdiction over the Padano-Venetian ichthyographic district and the rest of peninsular plus insular Italy, respectively $[9,10]$. Massive acclimatization and translocation activities ( 12 billion fishes of different species, including 16 non-native species) were rapidly implemented in the following 50 years, slowing down after 1945 [10].

During the $20^{\text {th }}$ century, the synergistic effects of the growing anglers' demand for more fish and the habitat degradation associated with urbanization increasingly impacted recreational fisheries. As a result, the goal of the fish-culture industry shifted from essentially seeding new self-sustaining non-native populations to enhancing the fish populations by stocking. This subsequently triggered dramatic conservation and management issues. Artificially stocking more manufactured fish than the ecosystems' carrying capacity and redefining nature as a play garden temporarily allowed to ignore the ongoing environmental damage [11]. Further, massive stocking of non-native trouts started to severely impact native assemblages, both ecologically and genetically, due to the widespread interfertility among salmonid taxa, e.g. [12].

In the 1960s, after World War II, alongside put-and-take fishery practices, the modern ecological movement and the concepts of wild trout management and ethics gradually developed in the USA, initially focusing on pollution, habitat degradation and fragmentation, and then extending to fishing regulations and restoration of wild native populations. Harsh confrontations between conservationists and advocates of stocking sparked everywhere, from USA to South Africa, being described as the 'trout wars' [3].

In Italy, stocking activities dramatically increased in 1970s, after the management of inland waters passed to the provinces in 1974 [9,10]. For at least the subsequent 25 years, stocking was conducted by few large aquaculture facilities. The largest one, located in the Veneto region, was widely used by several northern and central Italian provinces to stock massive amounts of several poorly-determined fish species from the Padano-Venetian province, vaguely defined "pesce bianco" (literally: "white fish" [9]). More recently, government compliance with European legislation [13] confirmed the prohibition to stock non-native fish species and populations into Italian waters, unless a site-specific environmental impact assessment demonstrates the lack of negative impacts on native species and environment $[14,15]$. The government proposed a reference list of Italian native and non-native species of interest in the fisheries sector. Among the non-native fishes there is 
one of the world's worst invasive species, the Atlantic brown trout S. trutta Linnaeus 1758 [16], which has been the backbone of the stocking and sportfishing Italian industries for almost two centuries. Even more recently, an amendment to the national Budget law [17] has been proposed [18] to suspend the application of these laws [14,15] until 2023. A harsh conflict is taking place between stakeholders prioritizing the genetic and ecological diversity of native populations, mainly including fishery scientists plus some anglers and managers, and those prioritizing the exploitation of inland fisheries, mainly including fish culturist, anglers, sportfishing associations, the hydropower private sector, and the majority of province and regional administrations. This clash was particularly dramatic in the industrialized north of Italy, home to the Italian Alpine and subalpine trout populations, and source of most of the revenues of the national stocking and angling industries. This 'Italian trout war' also provoked heated debates on the taxonomic and genetic identity of the stocked trouts, e.g. [19], and on the native status of trout species, e.g. [20,21,22,23]. Since 5-10 years, several Italian fish-culture companies started to introduce massive amounts of non-native stocks of peninsular trout (section 2) in this and other regions. Such stocks are collected from several locations in peninsular and insular Italy, including domesticated progeny often hybridized with non-native Atlantic stocks [19]. These were sold as 'Mediterranean trout', e.g. [24], and currently advertised as a conservationfriendly alternative to the non-native Atlantic brown trout. Some authors also hypothesized the presence of viable native populations of a peninsular trout lineage (i.e., S. cenerinus; sections 2,4).

On the other hand, the current global interest in trouts initiated environmental ethics and angler-driven conservation initiatives (e.g., Trout Unlimited in USA; Balkan Trout Restoration Group in Slovenia; numerous European LIFE projects). Shared attachment to place, characterizing a wide range of fish enthusiasts, from anglers to fishery scientists [3], could raise scientific awareness and foster collaboration among different stakeholders. This could develop global networks of multiple parties addressing issues such as sustainability, wild management, and transboundary conservation issues, such as climate change, pollution, and obstacles to fish movements (e.g., dams).

We review here the state of art of the taxonomy and evolution of the Italian trouts, clarifying our scientific view of these topics, and proposing future directions for a scientific approach to the conservation and ecosystem management of the fishery resources and inland waters of northern Italy.

\section{Native Italian trouts and the taxonomy of the 'peninsular trout'}

Among the valid nominal taxa [25] of the native trouts described in the Italian peninsula and the major Italian islands, Salmo cettii Rafinesque-Schmaltz 1810 was described from Sicily; type locality: Val Demone in northeastern Sicily and Val di Noto in southeastern Sicily, no types known [26]. S. marmoratus (Cuvier 1829) is a subendemism of northern Italy described from the "lacs de Lombardie"; syntypes not available [25,27] (section 3). S. cenerinus Nardo 1847 was described from northeastern Italy; type locality: not far from the sea, in rivers draining to the Venetian lagoon; no types known. The original description of S. cenerinus was provided in the early 1800 s by S. Chiereghin, and published posthumously [28]; a summary of this description was first published by Nardo [29]. Several authors considered S. macrostigma (Duméril 1858) as an Italian trout; however, it was described from North Africa (type locality: Oued-el-Abaïch, Kabylie, Algeria [30]). S. ghigii Pomini 1941 was described from central Italy (type locality: Sagittario River; no types known [31]). S. fibreni Zerunian \& Gandolfi 1990, described from the Lake Posta Fibreno in central Italy, and S. carpio Linnaeus 1758, described from Lake Garda, are restricted endemisms defined by ecomorphological and genetic traits [32]. The island of Sardinia might host an undescribed Salmo species [12].

The short description and illustration of S. cenerinus [29] may correspond to the pelagic morph of several anadromous Salmo species ([33,34], pers. obs). Nardo [35] modified his previous view [29], raising doubts on the original description of S. cenerinus, accepting 
the view of [36] (cited as 1858 by [35]), and eventually considering this taxon as a synonym of Trutta fario L. (= S. trutta). Heckel and Kner [36] reported only two trout species from the Venetian Provinces: Salar Ausonii Valenciennes 1848 [37] (= Trutta fario L. sensu [35]) and Fario carpio (= Trutta carpio sensu [35]= S. carpio) from the Garda Lake. While Salar genivittatus Hecker and Kner 1858 was subsequently recognized as a morph of S. marmoratus [38], Heckel and Kner [36] considered S. marmoratus as a color morph of Salar Ausonii. Therefore, Nardo [35] likely considered the marble trout of this region as color morphs of Trutta fario.

Kottelat [38] assigned S. cettii to the native peninsular Tyrrhenian and southern Italian trout, including islands, and "tentatively" assigned S. cenerinus to the native northItalian (Adriatic) peninsular trout. Consistently, he did not consider S. cenerinus as jun. syn. of S. marmoratus, since "there would be no available name for the present species and it should be either listed as Salmo sp. or a new name should be created for it". Kottelat [38] also synonymized S. ghigii with S. cettii apparently only because Pomini [31] was unable to discriminate the trouts of the Sagittario River from the Sardinian trouts. Kottelat \& Freyhof [39] accepted the point of view of Kottelat [38], while noting that "recent studies (...) suggest that the trouts of Sicily (...) belong to a distinct molecular lineage (...). If confirmed, this lineage should retain the name S. cettii; the name S. ghigii would probably be the valid name of the others".

Using combined mitochondrial (mtDNA) and nuclear (nDNA) markers, Segherloo et al. [12] found a close relationship between the Sicilian trout of Val di Noto and Atlantic $S$. trutta. A consistent result was found by another nuclear phylogenetic study of the Moroccan trouts, which included the Sicilian trout of Val di Noto in a robust 'Afro-Atlantic clade', likely originated from a colonization wave of an Atlantic lineage from Iberia (Duero; [40]). The only North-African sample analyzed by Segherloo et al. [12], that these authors tentatively assigned to Salmo pellegrini Werner 1931, is closely related to Mediterranean and Adriatic brown trouts, thus clearly belonging to a different lineage; this sample comes from the Oum er-Rbia River, where Snoj et al. [40] identified trouts of an 'Atlas clade'. Several studies showed that the Sicilian trout are morphologically distinct from other Italian trouts $[30,41,42,43,44]$. Mitochondrial phylogenies also show that the Sicilian trout is included in a clade of North-African trouts, also including the sequenced types of S. macrostigma [45] and the Atlantic lineage, called the "Southern Atlantic clade" [46,22]. However, no nuclear or combined mitochondrial and nuclear phylogenies were ever constructed including the types of $S$. macrostigma.

Rafinesque-Schmaltz [26] described S. cettii from two trout populations: Val di Noto and Val Demone. The molecular phylogeny of $S$. cettii has been investigated only using the former population, since no genetic samples have ever been collected and analyzed from the Val Demone, which has likely been extirpated [47]. The recovery and analysis of any such molecular sample (e.g. from a museum lot) would have important consequences on the scientific names of Italian trout lineages. There are 3 possible scenarios: (i) the Val Demone population belongs to an undescribed endemic trout lineage; (ii) the Val Demone population is conspecific with the peninsular trout; and (iii) the Val Demone and Val di Noto populations are conspecific (Figure 1). 

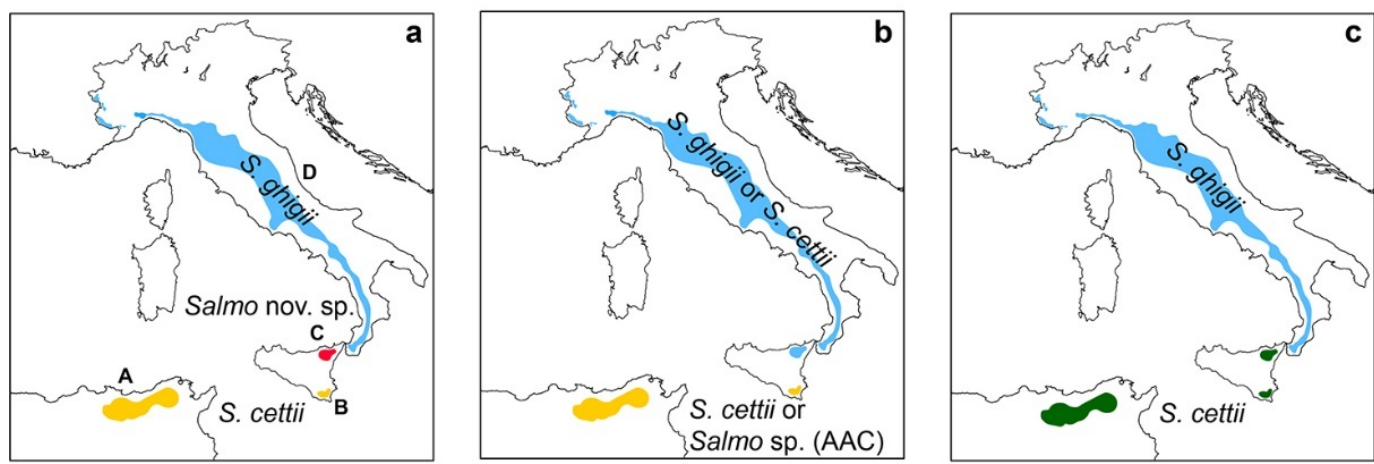

Figure 1. Three possible taxonomic scenarios (peninsular and Sicilian trouts, plus a North-African trout) if native trout samples are collected and analyzed from the Val Demone (no material presently available); (a) The native Val Demone population belongs to an undescribed and endemic lineage; (b) The native Val Demone population is conspecific with the peninsular trout; (c) The Val Demone and Val di Noto populations are conspecific. A: hypothetical distribution of a trout taxon of the 'Afro-Atlantic clade' (AAC), conspecific with the Val di Noto trout population [40]; B and C: Val di Noto and Val Demone populations, respectively, both described as S. cettii by Rafinesque-Schmalz [26]; the latter has likely been extirpated; D: peninsular trout, distribution range modified from [48]. No types are known for both S. ghigii and S. cettii. The taxon S. cettii is older than all North-African trout taxa [48].

In the first scenario (Figure 1a), the Val di Noto and the North-African Afro-Atlantic clade (sensu [40]) would be classified as S. cettii (older than any North-African trout taxon so far described [48]), the peninsular populations as S. ghigii, and the Val Demone population would belong to a new species that would require formal description. In the second scenario (Figure 1b), the collection of Rafinesque-Schmaltz [26] contained 2 distinct taxa. In the absence of type material, it is arbitrary whether to assign either of the two sampled populations to S. cettii. Therefore, there are two possibilities: either (a) Val di Noto plus the North-African populations could be classified as S. cettii, and Val Demone plus peninsular populations as S. ghigii, or (b) Val Demone plus peninsular populations could be classified as S. cettii, and Val di Noto plus the North-African population (Afro-Atlantic clade, AAC [40]) as one of the four North-African Salmo species (including S. macrostigma [48]), or as a new and yet undescribed species. In the third scenario (Figure 1c), the Sicilian trout plus AAC would be S. cettii, and the peninsular populations would be S. ghigii. In the absence of material from the Val Demone, we adopt a classification consistent with the third and most parsimonious scenario.

With the limitation of substantial sample biases, several studies did not find genetic or ecological discontinuities between native northern (southwestern Alps [49]) and central-southern peninsular trout lineages that would justify the designation of different taxa, except S. carpio and S. fibreni $[20,32,50,51,52,53,54]$. Segherloo et al. [12] assigned trout samples of the Po and Isonzo basins (northern slope of the Italian Apennine range) to $S$. cf. cenerinus, and samples of the Zrmanja to Mornos basins (Balkan peninsula) to Salmo farioides Karaman 1938, in the same region of its type locality (Krka River, Croatia; no types available [55]; neotype designated by Bianco [56]). S. cenerinus was found in brackish conditions [28]; however, the only native Italian trout recorded in the sea is S. marmoratus [57]. Further, there presently are no known native populations (nor genetic signatures of past populations) of peninsular trout in the area where S. cenerinus was described. On the other hand, anadromous non-native populations of $S$. trutta, including hybrids, are known to occur in the Adriatic region, including Italian waters [58,59]. Consequently, the hypothesis that the trout described by Chiereghin was a pelagic morph of $S$. trutta cannot be ruled out, since several fish-culture projects were active in this region in the second half of the $19^{\text {th }}$ century [35]. Borroni and Grimaldi [8] just reported that introductions of non-native S. trutta had been occurring "for decades" in Italy in the "70s. Bianco and Delmastro [60] and Bianco [56] synonymized S. marmoratus and S. cenerinus based on the illustration of $S$. 
cenerinus, its anadromous habits [28,29], and information gleaned from Gridelli [61], who reported only the presence of the marble trout in the Venezia Giulia region, previous to stocking activities of non-native brown trouts. Gridelli [61] who reported the presence of the marble trout as the only trout species in the Venezia Giulia region, previous to stocking activities of non-native brown trouts, which started in 1934. However, Nardo's [29] Venetian Provinces of the 1850s (type locality of S. cenerinus) are geographically distinct from the Venezia Giulia region of the 1930s [62]. Bianco [56] synonymized S. ghigii with S. farioides, however: (i) no neotype of $S$. ghigii was designated, likely due to the difficulty of finding 'purebred' individuals in the type locality; (ii) no molecular analyses were conducted; and (iii) the synonymy was essentially based on coloration patterns and biogeographical reconstructions. Therefore, we choose not to consider S. ghigii as a junior synonym of $S$. farioides. As a result, until further genetic and ecological data are made available on Tyrrhenian and Adriatic native Italian trouts, we choose to consider S. cenerinus as jun. syn. of S. marmoratus sensu Bianco [56] and S. ghigii as a valid name for all the populations of Italian peninsular trout, sensu Zanetti et al. [63] and Lorenzoni et al. [64].

\section{Phylogeny and phylogeography of $S$. marmoratus}

Nuclear phylogenetic reconstructions and molecular clocks defined a robust $S$. marmoratus clade, including two distinct northern and southern Adriatic clades that diverged $\sim 0.84 \pm 0.4$ million years ago (mya) $[65,66]$, and whose taxonomic status has not yet been evaluated. S. marmoratus is closely related to a 'S. trutta complex' lineage, including several clades associated with different brown-trout taxa [66]. These latter authors estimated the divergence between these two lineages at 1.4 \pm 0.8 mya (2.2-0.6 mya). A fossil-calibrated nDNA phylogeny estimated an earlier divergence, at $4-5$ mya [67]. An extensive molecular phylogeny combining nDNA and mtDNA sequences rooted with $S$. salar, essentially consistent with previous nDNA phylogenetic reconstructions, supported S. marmoratus as a phylogenetic species of possibly hybrid origins, sister to a clade including $>20$ Salmo species [12].

Northern Adriatic S. marmoratus populations are strongly associated with the 'Marmoratus' (MA) haplogroup of the mtDNA control region (D-loop) [22,68,69,70,71]. However, MA haplotypes have also been found in several brown trout taxa and populations of Greece, Albania, Croatia, Italy, and Corsica, e.g. [23,48,65,70] (section 4). Like several other brown trout taxa and populations, Southern Adriatic S. marmoratus populations are associated with the Adriatic (AD) mtDNA haplogroup [71].

Mitochondrial molecular clocks estimated much more recent origins of the MA and AD haplogroups (0.21-0.05 mya and 0.39-0.13 mya, respectively, considering the 95\% highest probability density intervals estimated using two different substitution rates [23]) than the time of divergence between $S$. marmoratus and the $S$. trutta complex. It was suggested that the observed mitochondrial-nuclear phylogenetic discordance might be the effect of incomplete lineage sorting or asymmetric introgressive hybridization (mtDNA capture; e.g. [72]). The much older time of divergence between these lineages relative to the time of haplogroup differentiation strongly supports the latter mechanism. Paleointrogressive hybridization between the marble trout and the Apennine Mediterranean trout could have occurred during several secondary contacts as a consequence of the expansion of the Po paleo-basin during glacial maxima, as it occurred in other Salmo species $[22,32,53,59,65,73]$. Mosaic distributions of mtDNA haplogroups among different taxa are common also in areas without a history of non-native trout's stocking (e.g., Albania [74]), and similar distributional and diversity patterns might have occurred in Italy after the Last Glacial Maximum (LGM 18,000 years ago).

Phylogenetic patterns, molecular clocks and the zoogeography of congeners suggest that S. marmoratus is one of the Salmo lineages that diverged in the palaeo-Adriatic drainage, in freshwater refuges formed during the preceding Lago Mare phase ( 5 mya). During the Pleistocene, reduced salinity, cooler sea temperatures, and extensive palaeo-river basins would have facilitated the westward dispersal of these freshwater lineages across 
the region through multiple waves of colonization, bottlenecks, and secondary contacts $[32,71,74]$, allowing $S$. marmoratus to colonize the orographic left tributaries of the palaeoPo basin [56,75,76]. After the LGM, increased salinity levels and sea-level rise disconnected these populations, facilitating allopatric fragmentation and differentiation of mtDNA lineages, resulting in the present geographic distribution [32].

In the northern Adriatic basin, S. marmoratus exhibit a west-to-east geographic gradient in MA-s1 and MA-s2 haplotype distribution, consistent with the described stepwise westward migration and phylogeographic scenario [77]. Significant microgeographic genetic differentiation was also measured within basins, e.g. between rivers and their tributaries, suggesting the presence of limited gene flow among different populations [78,79]. A contact zone between S. marmoratus and S. ghigii was found in the Southwestern Alps (section 4).

\section{Presence of $S$. ghigii in the Italian Alpine and subalpine region}

Within the Italian Alpine region [80], viable native populations of S. ghigii (section 3) have only been found in the Southwestern Alps (Cottian and Maritime Alps, upper Chisone, Pellice, Po, Stura Demonte, Gesso, and Tanaro basins), where a contact zone with $S$. marmoratus was described [20,21,23,34,48,50,76,79,81,82]. The MA, AD and 'Mediterranean' (ME) haplotype probability densities relative to elevation show an altitudinal zonation suggesting local habitat differentiation between the two sympatric species, with $S$. marmoratus being dominant at 0-1000 m above sea level (asl) and S. ghigii at 1000-2000 m asl [23]. These findings are consistent with historical accounts $[83,84,85]$. The Southwestern Alps are a known glacial refuge, where native populations of $S$. marmoratus and $S$. ghigii could have survived the LGM [81]. Introgression rates of alien Atlantic genes into native trout populations are here highly variable (0-70\%; [20]).

In contrast, in most of the Northwestern and Eastern Alps only the lower tracts of the rivers were unaffected by the ice cap during the LGM. Assuming that S. ghigii and S. marmoratus exhibited a habitat segregation pattern analogous to that presently observed in the Southwestern Alps, the LGM likely allowed the survival of S. marmoratus at lower altitudes, while $S$. ghigii might have been pushed into the marble trout habitat and outcompeted [81]. Similarly, S. marmoratus can rapidly displace brown trout (S. trutta fario= S. ghigii or S. trutta) when restocking practices are interrupted [86]. After the glaciation, upper isolated habitats and headwaters may have only marginally been colonized by $S$. marmoratus and likely remained "fishless" (i.e., troutless), until being stocked with translocated trout by anthropogenic activities, e.g. [87-89]. Introductions and stocking dramatically increased in the $19^{\text {th }}$ century, flooding these systems with non-native Atlantic $S$. trutta, e.g. [81]. Consistently, introgression rates of Atlantic S. trutta into S. marmoratus are consistently higher in this region, and only traces of the haplotypes associated with native S. ghigii were found $[21,81]$.

In the Eastern Alps, mitochondrial variants typically associated with S. ghigii (AD and ME haplotypes [50,70]) have been found in the Lake Garda basin, a known glacial refugial area [90], where the past presence of native $S$. ghigii was also supported using a probabilistic approach [91]. These findings are also consistent with the presence of AD and ME haplotypes of $S$. carpio, a possible signature of a paleohybridization event that occurred in Lake Garda [20,23,50,53]. Also the analysis of several museum specimens collected in the second half of the $19^{\text {th }}$ century revealed the presence of AD haplotypes, typically associated with S. ghigii in Lake Garda and Lake Maggiore (1877 and 1879, respectively), in specimens with a typical lacustrine phenotype [82]. Lake Maggiore is also known as a glacial refugium [90,92].

The allozymic variants $\mathrm{LDH}-\mathrm{C} 1^{*} 100$ and $\mathrm{TF}^{*} 102$ are considered diagnostic of Adriatic and other Mediterranean populations, being fixed in purebred trout populations native in France and northern Italy (S. ghigii: contact zone in the Southwestern Alps), and found at high frequency in Danubian native populations [49,93,94]. Largiadèr \& Scholl [95] assumed the native status of an "Adriatic fario" in the Po basin, based on molecular 
studies conducted in the contact zone [49] and on phenotypic studies that were however unable to discriminate between Atlantic (S. trutta) and Adriatic (S. ghigii) phenotypes [96]. These authors found these two allozymic variants at high frequency $(\sim 20 \%-30 \%)$ in Engadin (Danubian basin), in the Müstair, tributary of the Adige River, and in the Poschiavo valley (Po basin, Poschiavino Torrent, tributary of the Adda River); and at low frequency $(\sim 0 \%-10 \%)$ in the Ticino and Valais basins, including a tributary of the Diveria Torrent (Chrummbach); no 'purebred' individual were found. In fact, all these populations had been directly or indirectly (via Poschiavo hatcheries) either entirely replaced or heavily stocked with trout lineages of the Danubian basin for at least one century before the study collection [95]. This might explain the genetic similarities between the trouts of the Poschiavino and Ticino valleys, detected using microsatellite and AFLP markers to investigate the adaptive divergence and phylogeographic patterns of trout populations of the Rhine, Rhone, and Po basins [97,98]. Both these studies assumed the presence of Adriatic trout (S. cenerinus, sensu [39]) in the Poschiavino and Ticino valleys, based on the literature $[39,95,96]$. Given the lack of Danubian genetic references (allele size range), it is not possible to know whether the observed "Adriatic" signatures in the Poschiavino and Ticino valleys were originally present in this region, or were left by introduced Danubian stocks [97], as also suggested by the presence of Danubian haplotypes in the Ticino basin [77]. Both these studies also found evidence of introgression of the Poschiavo population into one Rhine population (SE). SE is the closest Rhine population to the Danubian drainage, suggesting the presence of stocking activities and translocations between SE, Poschiavo, and Danubian systems.

There are several descriptive accounts (cuisine recipes, anecdotes, poetry, and even paintings; e.g. [99]) of trouts in the Northwestern and Eastern Alps (e.g., Lakes Como and Garda basins) before the dramatic expansion of the stocking of northern European Atlantic S. trutta in the early $19^{\text {th }}$ century $(1850-1893,[10])$, e.g. $[100,101,102,103,104,105,106,107]$. Several ones depict or describe trouts without a marbled coloration pattern and with either red and black dots phenotypically compatible with several trout taxa, or with speckled dark patterns on a silvery background, compatible with a generalized pelagic morph of anadromous trout. Adult S. marmoratus living in rivers typically exhibit a marbled coloration pattern [108]; however, anadromous individuals in pelagic conditions can exhibit a silvery and dark-speckled coloration pattern, even leading to taxonomic confusion, e.g. [109]. 
a

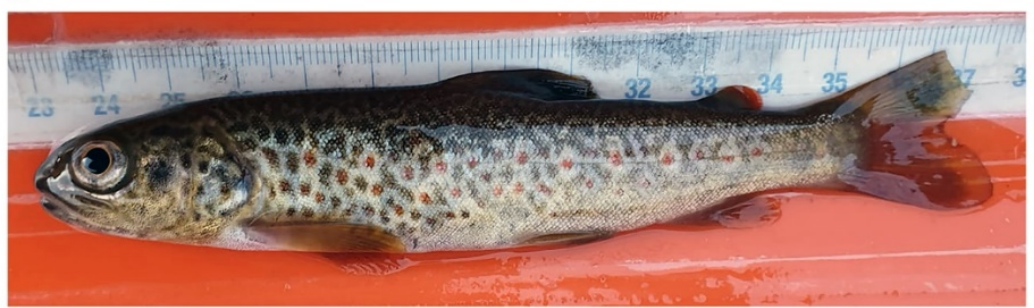

b

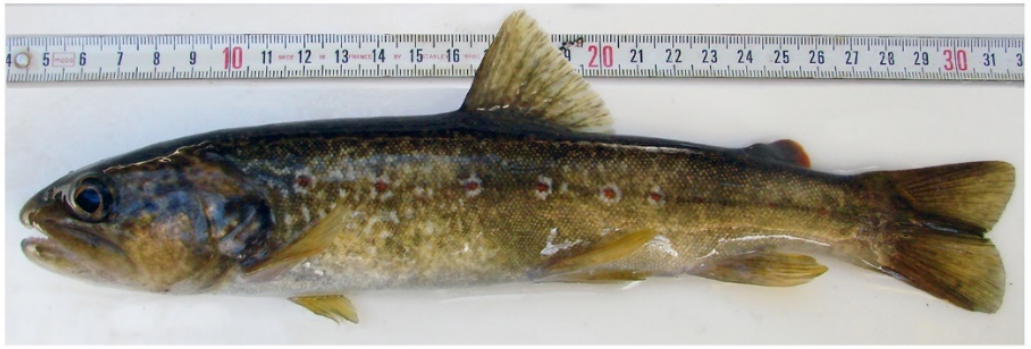

C

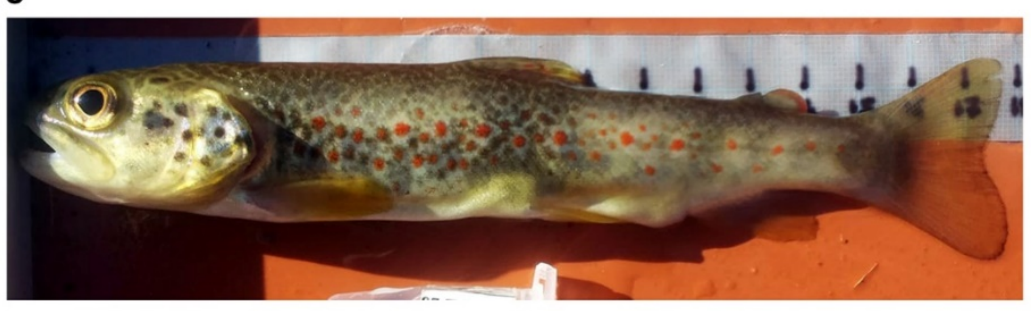

Figure 2. Examples of dotted coloration patterns in S. marmoratus: juvenile coloration pattern (a), and adults living in small and fast-flowing streams (b, c); (a) Juvenile from Roledo (Piedmont, Verbano-Cusio-Ossola: VCO; 46¹0'16.7"N 8¹8'49.7"E), $15.5 \mathrm{~cm}$ total length - TL, 29.0 g wet mass, 22 months of age, black-and-red dotted pattern, MA haplogroup, qMa 0.995 (admixture proportion of a cluster including purebred S. marmoratus references), 90\% BCI 0.966-1.000; (b) Adult (reproductive) specimen from Rio Ischielle, tributary of the Avisio Torrent (Province of Trento); the specimen was collected from a population which resided for 2 generations in this small stream, and descended from hatchery-reared S. marmoratus collected from the Adige River [110]; $26.9 \mathrm{~cm}$ TL, courtesy of Leonardo Pontalti; (c) adult (reproductive) specimen from Rio della Balma, tributary of the Sangone River (Province of Torino), 18.5 cm TL, MA haplogroup, qмa 0.996, 90\% BCI 0.978-1.000, courtesy of Paolo Lo Conte. 
a

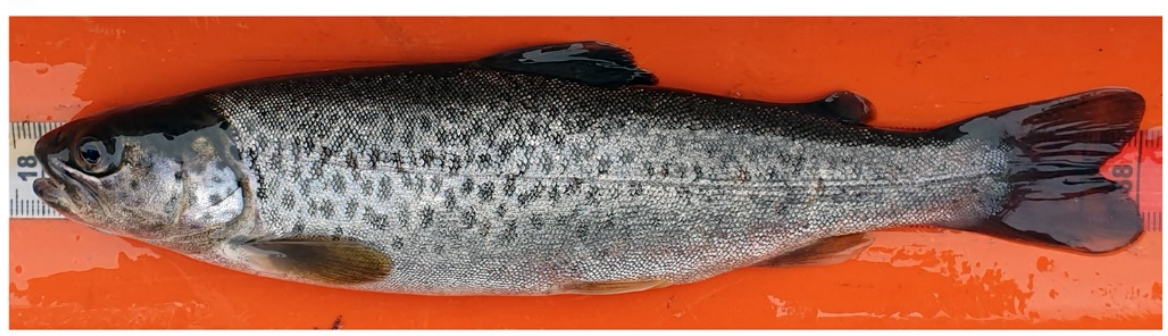

b

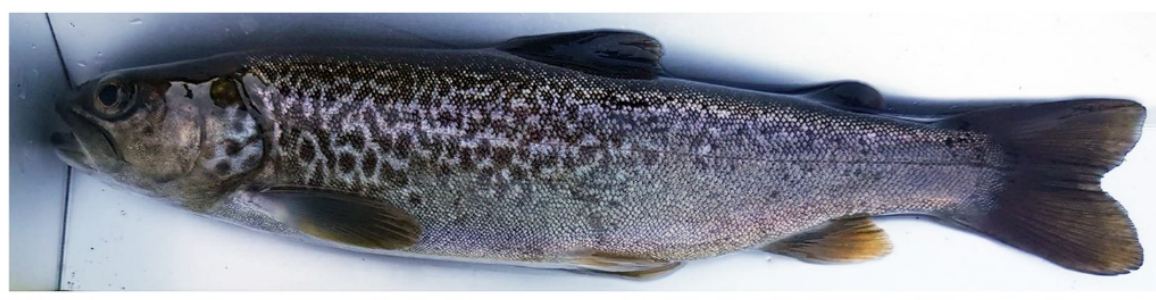

C

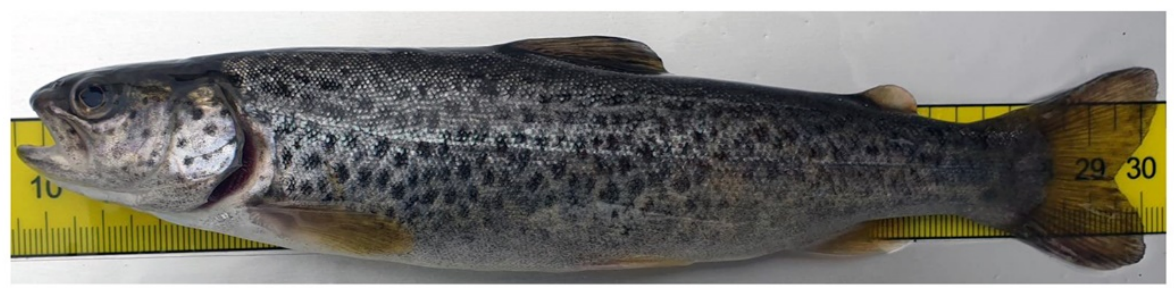

d

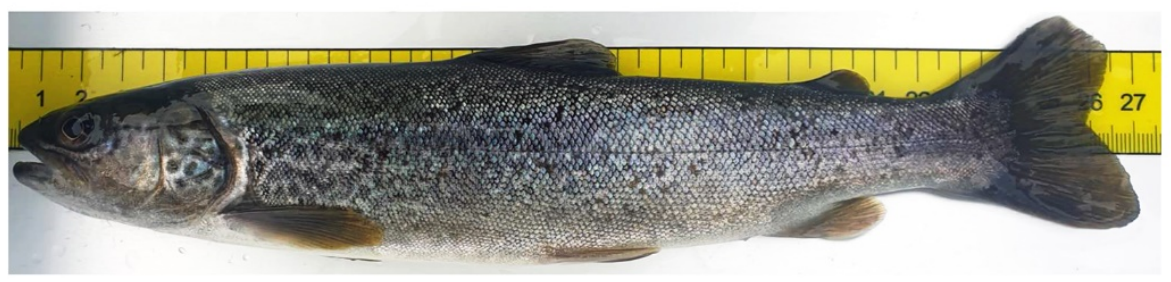

Figure 3. Examples of dotted coloration patterns in S. marmoratus: conspicuous ontogenetic chromatic variation in pit-tagged individuals which were recaptured at different times; (a) and (b) Subadult specimen sampled in Roledo (Piedmont, Verbano-Cusio-Ossola: VCO; 46 $10^{\prime} 16.7^{\prime \prime} \mathrm{N}$ $\left.8^{\circ} 18^{\prime} 49.7 " \mathrm{E}\right)$, age and genetic data unavailable; (a) Sampled on 28 April 2021, $20.0 \mathrm{~cm}$ TL, $86 \mathrm{~g}$, dotted pattern; (b) Recaptured in the same site on 28 October 2021, $23.4 \mathrm{~cm}$ TL, $122 \mathrm{~g}$, marbled pattern; (c) and (d) Subadult specimen sampled in Prata di Vogogna (Piedmont, VCO; 46'1'40.8"N 8¹7'2.2"E), age and genetic data unavailable; (c) Sampled on 26 April 2021, $20.6 \mathrm{~cm}$ TL, weight not available, dotted pattern; (d) Recaptured in the same site on 19 October 2021, $26.4 \mathrm{~cm}$ TL, $166.0 \mathrm{~g}$, marbled pattern.

Young marble trout typically exhibit an irregular black or black-and-red dotted pattern, with a large black preopercular blotch [108] (Figure 2a); the dark dotted pattern can change to a marbled pattern in a few months in subadults (Figure 3a-d); and adults living in small and fast-flow streams can mature at half the typical length at maturity, while retaining a red-dotted pattern [110] (Figure 2b,c). On the other hand, there is ample evidence of salmonid introductions in old historical times from outside Italy. Translocations and domestication practices of freshwater fishes, even across mountain ranges, go back to the Middle Ages and possibly to the Neolithic, seamlessly continuing through to the $18^{\text {th }}$ and $19^{\text {th }}$ century, before the onset of the fish-culture industry $[10,111,112,113,114]$. Nonnative trouts could have been introduced in northern Italy from adjacent regions, north of the Alpine Divide (e.g., from the Danube basin), just like the common carp Cyprinus carpio 
L. in the Roman Period [10,115], or from the orographic right tributaries of the Po River (section 5).

Historical local extinctions of S. ghigii in the Northwestern and Eastern Alps might also have occurred in historical times, through hybridization and demographic swamping [116], caused by the massive stocking of Atlantic S. trutta over the last two centuries. This type of scenario was tested for trout populations of the Lake Garda basin, using a probabilistic approach [91]. Such dramatic effects could have been facilitated by strong numerical differences between native populations and introductions, low hybrid fitness, and very weak reproductive barriers. The presence of partial reproductive barriers between non-native S. trutta and S. marmoratus [79,117], and marble-trout stocking could have prevented the lineage or local genomic extinction of $S$. marmoratus. On the other hand, in spite of the presence of high introgression rates [81], neither demographic swamping nor local genomic extinctions of native Apennine S. ghigii have ever been described in the TuscanoLatium Italian ichthyogeographic region, where non-native $S$. trutta have been and are being introduced.
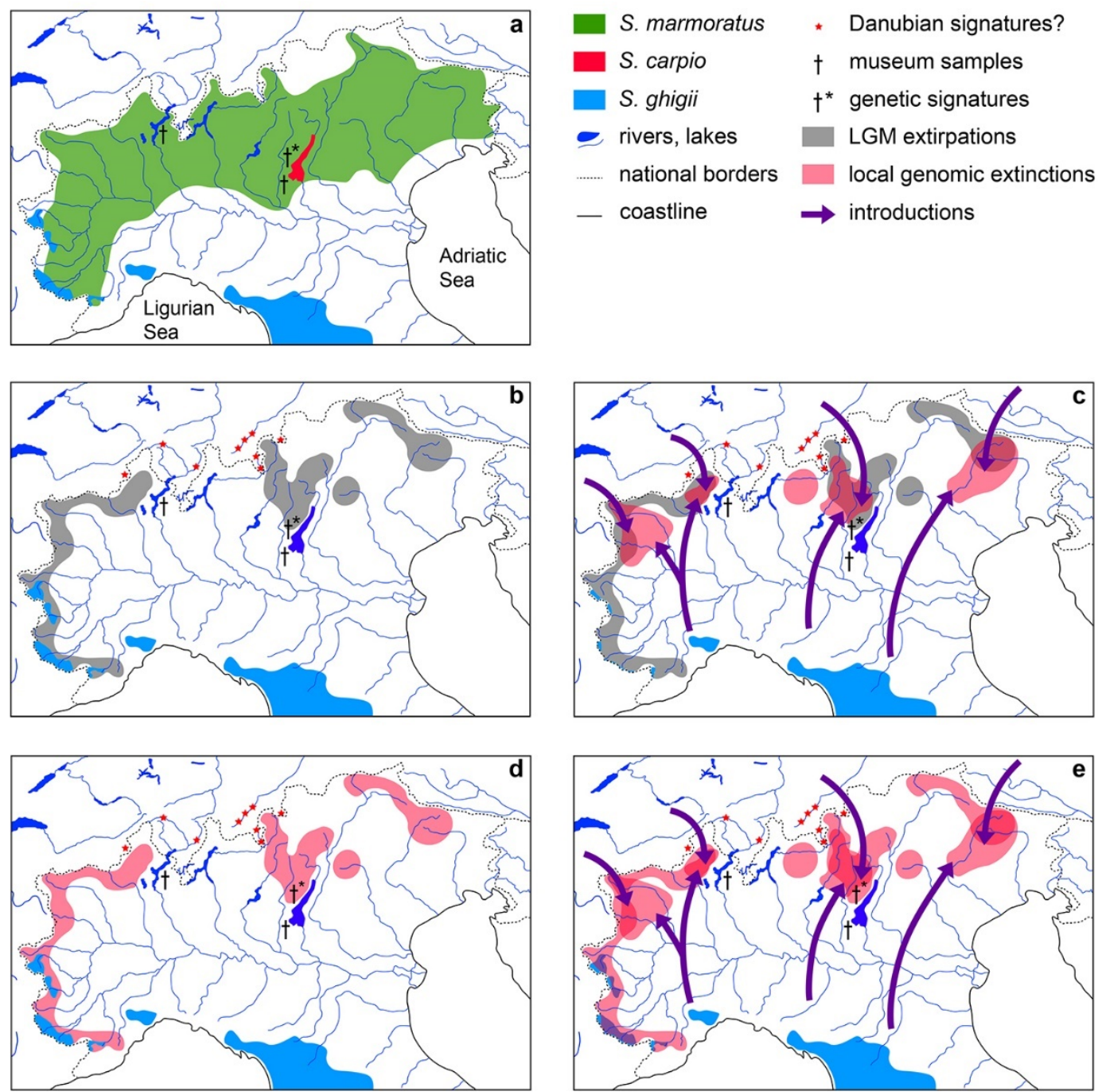

Figure 4. Present distribution of the north-Italian trouts and hypothetical reconstructions of the demographic history of $S$. ghigii in this region; (a) Alpine and subalpine trouts on the Italian territory, modified from $[23,48,118]$, and presence of genetic signatures of extirpated populations of S. ghigii; (b) Hypothetical distribution of S. ghigii before LGM, and subsequent extinction during LGM, without subsequent introductions of this species in historical times; (c) As in (b), but with subsequent introductions from areas outside the original distribution; (d) Hypothetical distribution of S. ghigii after the LGM, assuming no extinction occurred during LGM, without subsequent introductions in 
historical times, and subsequent genomic extirpation caused by massive introductions of non-native Atlantic S. trutta; (e) As in (d), but with subsequent introductions of S. ghigii from areas outside its original distribution. In legend, Danubian signatures? refers to the possible presence of genetic variants introduced from the Danube basin (see text); museum samples: preserved records of the Adriatic lineage's haplotypes [82]; genetic signatures: traces of extirpated populations of S. ghigii [91].

Considering (i) the evidence of past widespread presence of $S$. ghigii in this region (before LGM), due to the estimated gene flow between the marble and peninsular lineages (section 5); (ii) the absence of viable populations in this region (with the described exception of Southwestern Alps), and the presence of genetic signatures of extirpated populations (Figure 4a); (iii) the hypothetical extirpation of native populations of S. ghigii in this region during LGM; (iv) the anecdotal historical accounts potentially reporting the presence of S. ghigii in this region in historical times; and (v) the possibility of recent extirpations of populations of $S$. ghigii due to local genomic extinction caused by massive introductions of non-native $S$. trutta; four potentially falsifiable scenarios can be hypothesized (Figure 4):

1. S. ghigii populations were extirpated in most of their range in this region during LGM (except the Southwestern Alps), and were never subsequently introduced from non-native populations (Figure $4 b$ ).

2. S. ghigii populations were extirpated in most of their range in this region during LGM, and were subsequently introduced from non-native populations (Figure 4c).

3. S. ghigii populations survived in this region during LGM, were extirpated by local genomic extinction due to the subsequent introductions of $S$. trutta, and were never subsequently introduced from non-native populations (Figure $4 \mathrm{~d}$ ).

4. S. ghigii populations survived in this region during LGM, were extirpated by local genomic extinction due to the subsequent introductions of $S$. trutta, and were subsequently introduced from non-native populations (Figure 4e).

In every scenario, $S$. ghigii has been extirpated in this region, and no native and viable populations are left, except in the Southwestern Alps. Therefore, any introduction from $S$. ghigii populations outside these sites should be considered an introduction of non-native (allochthonous) populations.

Notwithstanding, non-native populations of S. ghigii sourced from outside this region have been and are being regularly and massively introduced in the last decade. Such stocking activities will obviously hamper any future investigation attempting to assess the status of populations that may be found in the region. In fact, any new biological variant found in the region that is not present in any of the non-native source populations may still be non-native, i.e., being still undescribed in the source population. Therefore, if the societal priority and management goal is conservation, a precautionary principle should be applied, avoiding any introductions of $S$. ghigii in this region.

\section{Current risks of stocking non-native $S$. ghigii in northern Italy}

The risk of introgressive hybridization between native $S$. marmoratus and non-native stocks of $S$. ghigii is not only suggested by the widespread interfertility between Salmo species. The same presence of gene-flow signatures between these lineages during past secondary contacts before LGM [53] clearly demonstrates the potential for such events. This is particularly the case when native small and fragmented populations are flooded by large amounts of stocked non-native fish [81], in the same ecological conditions that caused the ongoing introgression between S. marmoratus and Atlantic S. trutta in this region [119].

The ongoing stocking of individuals of $S$. ghigii obtained from non-native populations is also associated with other risks. While hatchery managers introducing S. ghigii in this region typically do not publish any genetic screening of the stocks, an independent investigation in a different region showed that a hatchery stock of "Mediterranean trouts" actually contained a mix of both Atlantic haplotypes (44\%) and Mediterranean haplotypes 
$(66 \%)$, being characterized by a qAT value (admixture proportion of the cluster characterizing two hatchery stocks of non-native Atlantic S. trutta) of 0.42-1.00 [19]. Given the exceptional rarity of such independent investigations, such cases are more likely the rule rather than the exception. Introductions of such hybrid stocks pose an even greater risk than introductions of purebred non-native S. ghigii, since hybrids can effectively act as a bridge, facilitating hybridization and introgression between reproductively isolated species [120].

The dispute revolving around S. ghigii and the "Mediterranean trout" in northern Italy is also related to another hot and current topic, i.e. the management of stream headwaters. Stocking of native S. marmoratus generally occurs in what is considered to be its putative vocational habitat, i.e. in middle and lower river reaches $(<1500 \mathrm{~m}$ asl [86]). On the other hand, current regulations often prohibit the introduction of non-native species, such as the Atlantic brown trout (section 1). This caused a heated debate, fueled by anglers and sportfishing associations, who advocate the use of non-native stocks of S. ghigii to exploit stream headwaters. Most headwater streams in this region were likely troutless, prior to human settlement or stocking (section 4). While this hypothesis still lacks experimental support, the idea of stocking non-native $S$. ghigii in these environments is at odds with conservation principles (section 1). Headwater streams could also be stocked with non-native sterilized fishes, e.g. by a process of triploidisation, thus preventing hybridization with native species downstream. However, massive fish introductions can significantly impact the structure and functioning of freshwater ecosystems, due to interactions with the native communities and recipient environments, including increased competition, predation, biogenic modification of the environment, and potential spreading of diseases $[121,122,123,124,125,126]$. Therefore, the sustainability of this management strategy must be considered with extreme caution, carefully assessed, and regularly monitored after implementation.

\section{Conclusions and future directions}

At present, robust scientific evidence identifies S. marmoratus as the only native and distinct Salmo lineage and taxon in northern Italy except a contact zone in the Southwestern Alps, also inhabited by S. ghigii. Introgressive hybridization from non-native Salmo trutta into S. marmoratus in this region has been repeatedly demonstrated. Given the evidence of past introgression from the peninsular lineage into the marble lineage, genetic introgression from non-native stocks of $S$. ghigii into native $S$. marmoratus is a reasonable possibility.

Genetic signatures of $S$. ghigii outside the contact zone are fragmentary, and strongly suggest past extirpations. It is presently impossible to determine whether viable populations of this species were present in historical times, or most of the native populations were extirpated during the LGM.

Regardless of the academic value of taxonomic debates and the chronic state of flux of the taxonomic consensus, the high interfertility among many salmonid taxa makes a rational approach to the ecosystem management of salmonid populations extremely challenging. Any introduction of trout individuals originating from a non-native population defined by phylogeographic and genetic criteria, even if conspecific with the recipient population, poses the risk of generating hybrid swarms between non-native stocks and native trout lineages. For this reason, translocations, reintroductions, and supportive breeding of salmonid populations should always be managed as Evolutionary Significant Units (ESUs; $[32,127,128]$ ). Considering the genetic structure of populations at the microgeographic scale makes conservation actions taxonomy-independent, gaining the sorely needed stability for conservation purposes. In the specific case of reintroductions, using the closest available ESU as a source to rebuild an extirpated population poses the risk of introducing individuals with different life-history traits than those of the original population. For this reason, the potential impacts of reintroductions should always be carefully evaluated, in case prevented, and then monitored, e.g. [129] (sections 3, 4). 
Future research could (i) further our knowledge of the genetic structure and microgeographic patterns of $S$. marmoratus populations within the region, thus identifying ESUs for science-based conservation and management; (ii) investigate the past presence of $S$. ghigii populations in the Italian Alpine and subalpine region using ancient DNA, e.g. in archaeological sites [130] (e.g.,) or in ancient lake sediments [131]; (iii) investigate the past presence of salmonids in hypothetically fishless headwater streams prior to stocking, e.g. using museum records; (iv) investigate the presence of species of evolutionary and conservation interest evolved in hypothetically troutless headwater streams, and their potential interactions with non-native fish candidates for stocking; (v) monitor spatiotemporal dynamics of genetic diversity of trout lineages, both native and non-native, with special attention to the potential onset and development of new hybrid swarms originating from the recent introductions from S. ghigii non-native populations; (vi) investigate the genetic structure, ecology and conservation status of $S$. ghigii native populations in the Southwestern Alps, and design and implement dedicated conservation programs, if needed; and (vii) evaluate and implement supporting breeding programs for threatened and heavily fished ESUs of $S$. marmoratus, using state-of-the-art methods to genetically select breeders and minimize domestication effects.

Research efforts will however be insufficient to meet the common goal of sustainable ecosystem management [132], if all the stakeholders are not involved in a durable, empathetic, and collective effort. From anglers to sportfishing associations, hydropower sectors, researchers, conservationists, and governmental institutions, everyone is called to protect, conserve, and promote the native north-Italian trouts, hence preserving the natural heritage of our inland waters.

Author Contributions: Conceptualization, G.P. and P.V.; writing-original draft preparation, G.P.; writing-review and editing, G.P., T.R., M.I., P.V.; supervision, P.V.; project administration, P.V.; funding acquisition, P.V. All authors have read and agreed to the published version of the manuscript.

Funding: This study was funded by INTERREG ITA-CH SHARESALMO and LIFE15 NAT/IT000823 IdroLIFE Projects.

Data Availability Statement: Not applicable.

Acknowledgments: The authors would like to thank Leonardo Pontalti (Ufficio faunistico della Provincia di Trento) and Paolo Lo Conte (Città Metropolitana di Torino) for the photos of S. marmoratus from Rio Ischielle and Sangone River, respectively. We also thank Andrea Gandolfi (Fondazione Edmund Mach), Andrea Splendiani (Univ. Politecnica delle Marche), Leonardo Pontalti, Antonino Duchi (Legambiente Ragusa), Paolo Lo Conte, Cesare Puzzi (G.R.A.I.A. srl), Gian Mauro Bertoia and Umberto Grossi (F.I.P.S.A.S. VCO), Pierpaolo Gibertoni (M.T.R.G.), Valter Bianchini (U.P.S. Sondrio), Luigi Guglielmetti (A.P.S. Como), Giancarlo Perosino (C.R.E.S.T. Piemonte), and the numerous passionate anglers of northern Italy met in the last two years for the stimulating conversations revolving around this topic.

Conflicts of Interest: The authors declare no conflicts of interest. The funders had no role in the design of the study; in the collection, analyses, or interpretation of data; in the writing of the manuscript, or in the decision to publish the results.

\section{References}

1. Brookes, R. The Art of Angling. 5th edition, Lowndes T: London, UK, 1781; 304 p.

2. Hoffmann, R.C. Trout and fly, work and play, in medieval Europe. In Backcasts: A Global History of Fly Fishing and Conservation; Snyder, S.; Borgelt, B.; Tobey, E., Eds.; University of Chicago Press: Chicago, USA, 2016; pp. 27-45.

3. Brown, J.C.; Lokensgard, K.H.; Snyder, S.; Draper, M. The cultural currents and social values of trout. In Trout and Char of the World; Kershner, J.L.; Williams, J.E.; Gresswell, R.E.; Lobón-Cerviá, J., Eds.; American Fisheries Society: Bethesda, USA, 2019; pp. 65-93.

4. Yu, P.L. Rivers, Fish and the People: Tradition, Science, and Historical Ecology of Fisheries in the American West. University of Utah Press: Salt Lake City, USA, 2015. 
5. Kinsey, D. 'Seeding the water as the earth': the epicenter and peripheries of a western aquacultural revolution. Environ Hist 2006, 11(3), 527-566.

6. Draper, M. Holy trout: New Zealand and South Africa. In Backcasts: A Global History of Fly Fishing and Conservation; Snyder, S.; Borgelt, B.; Tobey, E., Eds.; University of Chicago Press: Chicago, USA, 2016; pp. 178-194.

7. Vinciguerra, D. I coregoni e la loro introduzione in Italia. L'eco dei campi e dei boschi 1895, 2, 2.

8. Borroni, I.; Grimaldi, E. Fattori e tendenze di modificazione dell'ittiofauna italiana d'acqua dolce. Italian J Zool (Boll Zool) 1978, 45(suppl. II), 63-73. DOI: 10.1080/11250007809440267

9. Bianco, P.G. L'ittiofauna continentale dell'Appennino umbro-marchigiano, barriera semipermeabile allo scambio di componenti primarie tra gli opposti versanti dell'Italia centrale. Biogeographia 1994, 17, 427-485. DOI: 10.21426/B617110467

10. Bianco, P.G. Freshwater fish transfers in Italy: history, local modification of fish composition, and a prediction on the future of native populations. In Stocking and Introductions of Fishes; Cowx, I.G., Ed.; Fishing New Book, Blackwell Science: Oxford, UK, 1998; pp. 167-185.

11. Halverson, A. An Entirely Synthetic Fish: How Rainbow Trout Beguiled America and Overran the World. Yale University Press: New Haven, USA, 2010.

12. Segherloo, I.H.; Freyhof, J.; Berrebi, P.; Ferchaud, A.-L.; Geiger, M.; Laroche, J.; Levin, B.A.; Normandeau, E.; Bernatchez, L. A genomic perspective on an old question: Salmo trouts or Salmo trutta (Teleostei: Salmonidae)? 2021, Mol Phylogenet Evol, 162, 107204. doi:10.1016/j.ympev.2021.107204

13. Council Directive. On the conservation of natural habitats and of wild fauna and flora. 1992, 92/43/EEC 21 May, OJ L 206, 22.7.1992, 7-50. Available online: https://eur-lex.europa.eu/legal-content/EN/TXT/?uri=celex\%3A31992L0043 (accessed on February 2022).

14. Decreto del Presidente della Repubblica 8 settembre 1997, n. 357. Available online: https://www.mite.gov.it/ (accessed on February 2022).

15. Ministero dell'Ambiente e della Tutela del Territorio e del Mare. Criteri per la reintroduzione e il ripopolamento delle specie autoctone di cui all'allegato D del decreto del Presidente della Repubblica 8 settembre 1997, n. 357, e per l'immissione di specie e di popolazioni non autoctone (20A02112). 2020, Gazz Uff Repubbl Ital, 98, 2-6. Available online: https://www.gazzettaufficiale.it/eli/id/2020/04/14/20A02112/sg (accessed on February 2022).

16. Lowe, S.; Browne, M.; Boudjelas, S.; De Poorter, M. 100 of the World's Worst Invasive Alien Species: A Selection from the Global Invasive Species Database; Invasive Species Specialist Group (ISSG, Species Survival Commission of the International Union for the Conservation of Nature): Auckland, New Zealand, 2000.

17. Presidente della Repubblica. Bilancio di previsione dello Stato per l'anno finanziario 2022 e bilancio pluriennale per il triennio 2022-2024 del 31 dicembre 2021 (21G00256). 2021, Gazz Uff Repubbl Ital, 310(suppl.), 1-404. Available online: https://www.gazzettaufficiale.it/eli/id/2021/12/31/21G00256/sg (accessed on February 2022).

18. Resoconti delle Giunte e Commissioni. Camera dei Deputati, XVII Legislatura. 2022, Boll Giunt Commissioni Parlam, 742 (allegato), 57-58. Available online: https:/www.camera.it/leg18/824?tipo=A\&anno=2022\&mese=02\&giorno=16\&view=filtered_scheda\&commissione $=0105$ (accessed on February 2022).

19. Splendiani, A.; Giovannotti, M.; Righi, T.; Fioravanti, T.; Cerioni, P.N.; Lorenzoni, M.; Carosi, A.; La Porta, G.; Caputo Barucchi V. Introgression despite protection: the case of native brown trout in Natura 2000 network in Italy. 2019, Conserv Genet, 65, 460473. DOI: 10.1007/s10592-018-1135-y.

20. Giuffra, E.; Guyomard, R.; Forneris, G. Phylogenetic relationships and introgression patterns between incipient parapatric species of Italian brown trout (Salmo trutta L. complex). 1996, Mol Ecol, 5, 207-220. DOI: 10.1046/j.1365-294X.1996.00074.x.

21. Meraner, A.; Gratton, P.; Baraldi, F.; Gandolfi, A. Nothing but a trace left? Autochthony and conservation status of Northern Adriatic Salmo trutta inferred from PCR multiplexing, mtDNA control region sequencing and microsatellite analysis. 2013, $\mathrm{Hy}$ drobiologia, 702, 201-213. DOI: 10.1007/s10750-012-1321-8.

22. Splendiani, A.; Palmas, F.; Sabatini, A.; Caputo Barucchi V. The name of the trout: considerations on the taxonomic status of the Salmo trutta L., 1758 complex (Osteichthyes: Salmonidae) in Italy. 2019, Eur Zool J, 86(1), 432-442. DOI: 10.1080/24750263.2019.1686544.

23. Splendiani, A.; Berrebi, P.; Tougard, C.; Righi, T.; Reynaud, N.; Fioravanti, T.; Lo Conte, P.; Delmastro, G.B.; Baltieri, M.; Ciuffardi, L.; Candiotto, A.; Sabatini, A.; Caputo Barucchi, V. The role of the south-western Alps as a unidirectional corridor for Mediterranean brown trout (Salmo trutta complex) lineages. 2020, Biol J Linn Soc, 131(4), 909-926. DOI: 10.1093/biolinnean/blaa125.

24. Gibertoni, P.P.; Pensierini, M. Trote native degli Appennini. 2008, H2O Mag, 1, 56-62.

25. Fricke, R.; Eschmeyer, W.N.; van der Laan, R. Eschmeyer's Catalog of Fishes: Genera, Species, References. Available online: http://researcharchive.calacademy.org/research/ichthyology/catalog/fishcatmain.asp (accessed on January 2022).

26. Rafinesque-Schmaltz, C.S. Indice d'Ittiologia Siciliana; ossia, Catalogo Metodico dei Nomi Latini, Italiani, e Siciliani dei Pesci, che si Rinvengono in Sicilia Disposti Secondo un Metodo Naturale e Seguito da un Appendice che Contiene la Descrizione de Alcuni Nuovi Pesci Siciliani; del Nobolo G: Messina, Italy, 1810.

27. Cuvier, G. Le Règne Animal, Distribué d'après son Organisation, pour Servir de Base à l'Histoire Naturelle des Animaux et d'Introduction à l'Anatomie Comparée, 2nd ed.; Déterville and Chrochard: Paris, France, 1829; Volume 2.

28. Chiereghin, S. Descrizione de' Pesci, de' Crostacei e de' Testacei che Abitano le Lagune ed il Golfo Veneto; Canova ed: Treviso, Italy, 2001; 2 volumes. 
29. Nardo, G.D. Sinonimia Moderna delle Specie Registrate nell'Opera Intitolata: "Descrizione de' Crostacei, de' Testacei e de' Pesci che Abitanno le Lagune e Golfo Veneto Rappresentati in Figure à Chiaro-Scuro ed a Colori"; Antonelli: Venezia, Italy, 1847.

30. Duméril, A.H.A. Note sur une truite d'Algérie (Salar macrostigma, A. Dum.). 1858, C R Hebd Acad Sci, 47, $160-162$.

31. Pomini, F.P. Ricerche sui Salmo dell'Italia peninsulare. I. La trota del Sagittario (Abruzzi): Salmo ghigii (n. sp.). 1941, Atti Soc Ital Sci Nat Milano, 80(1), 33-48.

32. Meraner, A.; Gandolfi, A. Genetics of the genus Salmo in Italy: Evolutionary history, population structure, molecular ecology and conservation. In Brown Trout: Biology, Ecology and Management; Lobón-Cerviá, J.; Sanz, N., Eds.; Wiley \& Sons Ltd: Hoboken, USA, 2018; pp. 65-102.

33. Zerunian, S. Iconografia dei Pesci delle Acque Interne d'Italia; Ministero dell' Ambiente e della Tutela del Territorio (Direzione Conservazione Natura). Unione zoologica Italiana. Istituto Nazionale Fauna Selvatica. Tipolitografia F.G. Savigliano sul Panaro: Modena, Italy, 2002.

34. Bovero, S.; Candiotto, A.; Ceppa, L.; Giuntoli, F.; Pascale, M.; Perosino, G.C. Stato dell'ittiofauna nei fiumi e torrenti del Piemonte. 2021, Riv Piemont Storia Nat, 42, 135-160.

35. Nardo, G.D. Cenni Storico Critici sui Lavori Pubblicati Specialmente nel nostro Secolo che Illustrano la Storia Naturale degli Animali Vertebrati della Veneta Terraferma ed Appendice Relativa ai Tentativi Fatti nelle Provincie Venete sulla Piscicoltura e sulla Propagazione Artifiziale del Pesce di Acqua Dolce. Grimaldo: Venice, Italy, 1875.

36. Heckel, J.J.; Kner, R. Die Süsswasserfische der Österreichischen Monarchie, mit Rücksicht auf die angränzenden Länder. Engelmann, W. (von): Leipzig, Germany, 1857.

37. Cuvier, G.; Valenciennes, A. Histoire Naturelle des Poissons. Tome vingt et unième. Suite du Livre vingt et unième et des Clupéö̈des. Livre vingt-deuxième. De la Famille des Salmonoïdes. Bertrand, P.: Strasbourg, France, 1848.

38. Kottelat, M. European freshwater fishes. 1997, Biologia (Bratislava), 52 (suppl. 5), 1-271.

39. Kottelat, M.; Freyhof, J. Handbook of European Freshwater Fishes. Kottelat M, Freyhof J.: Cornol, Switzerland and Berlin, Germany, 2007.

40. Snoj, A.; Bravničar, J.; Marić, S.; Sušnik Bajec, S.; Benaissa, H.; Schöffmann, J. Nuclear DNA reveals multiple waves of colonisation, reticulate evolution and a large impact of stocking on trout in north-west Africa. 2021, Hydrobiologia, 848, 3389-3405. DOI: 10.1007/s10750-021-04567-0.

41. Schöffmann, J. Autochthone Forellen (Salmo trutta L.) in Nordafrika. 1993, Österreichs Fischerei, 46, $164-169$.

42. Bobbio, L.; Cannas, R.; Cau, A.; Deiana, A.M.; Duchi, A.; Gandolfi, G.; Tagliavini, J. Mitochondrial variability in Italian trouts, with particular reference to "macrostigma" populations. Proceedings of the $6^{\text {th }}$ National Conference of AIIAD (Associazione Italiana Ittiologi Acque Dolci): Carte ittiche dieci anni dopo, Varese Ligure, Italy, 1996; pp. $42-49$.

43. Duchi, A. Flank spot number and its significance for systematics, taxonomy and conservation of the near-threatened Mediterranean trout Salmo cettii: evidence from a genetically pure population. 2017, J Fish Biol, 92(1), 254-260. DOI: 10.1111/jfb.13492.

44. Duchi, A. Extant because important or important because extant? On the scientific importance and conservation of a genetically pure Sicilian population of the threatened Salmo cettii Rafinesque, 1810. 2020, Cybium, 44(1), 41-44. DOI: 10.26028/cybium/2020441-005.

45. Tougard, C.; Justy, F.; Guinand, B.; Douzery, E.J.P.; Berrebi, P. Salmo macrostigma (Teleostei, Salmonidae): Nothing more than a brown trout (S. trutta) lineage? 2018, J Fish Biol, 93, 302-310. DOI: 10.1111/jfb.13751.

46. Fruciano, C.; Pappalardo, A.M.; Tigano, C.; Ferrito, V. Phylogeographical relationships of Sicilian brown trout and the effects of genetic introgression on morphospace occupation. 2014, Biol J Linn Soc, 112(3), 387-398. DOI: 10.1111/bij.12279.

47. Duchi, A. (Legambiente Ragusa, Ragusa, Italy). Personal communication, 2021.

48. Lobón-Cerviá, J.; Esteve, M.; Berrebi, P.; Duchi, A.; Lorenzoni, M.; Young, K.A. Trout and char of central and southern Europe and northern Africa. In Trout and Char of the World; Kershner, J.L.; Williams, J.E.; Gresswell, R.E.; Lobón-Cerviá, J., Eds.; American Fisheries Society: Bethesda, USA, 2019; pp. 379-410.

49. Giuffra, E. Identificazione genetica e filogenia delle popolazioni di trota comune, Salmo trutta L., del bacino del Po. Ph.D. thesis, University of Turin, Turin, Italy, 1993.

50. Giuffra, E.; Bernatchez, L.; Guyomard, R. Mitochondrial control region and protein coding gene sequence variation among phenotypic forms of brown trout Salmo trutta from Northern Italy. 1994, Mol Ecol, 3(2), 161-172. DOI: 10.1111/j.1365294x.1994.tb00117.x.

51. Patarnello, T.; Bargelloni, L.; Caldara, F.; Colombo, L. Cytochrome b and 16S rRNA sequence variation in the Salmo trutta (Salmonidae, Teleostei) species complex. 1994, Mol Phylogenet Evol, 3(1), 69-74. DOI: 10.1006/mpev.1994.1008.

52. Gratton, P.; Allegrucci, G.; Gandolfi, A.; Sbordoni, V. Genetic differentiation and hybridization in two naturally occurring sympatric trout Salmo spp. forms from a small karstic lake. 2013, J Fish Biol, 82, 637-657. DOI: 10.1111/jfb.12022.

53. Gratton, P.; Allegrucci, G.; Sbordoni, V.; Gandolfi, A. The evolutionary jigsaw puzzle of the surviving trout (Salmo trutta L. complex) diversity in the Italian region. A multilocus Bayesian approach. 2014, Mol Phylogenet Evol, 79, 292-304. DOI: 10.1016/j.ympev.2014.06.022.

54. Palombo, V.; De Zio, E.; Salvatore, G.; Esposito, S.; Iaffaldano, N.; D'Andrea, M. Genotyping of two Mediterranean trout populations in central-southern Italy for conservation purposes using a rainbow-trout-derived SNP array. 2021, Animals, 11, 1803. DOI: 10.3390/ani11061803.

55. Karaman, S. Prilog poznavanju slatkovodnih riba Jugoslavije. Glasnik Skopskog naučnog društva knj. 1938, Skopje, 18, 131-139. 
56. Bianco, P.G. An update on the status of native and exotic freshwater fishes of Italy. 2014, J Appl Ichthyol, 30, 62-77. DOI: 10.1111/jai.12291.

57. Soldo, A. First marine record of marble trout Salmo marmoratus. 2013, J Fish Biol, 82, 700-702. DOI: 10.1111/jfb.12036.

58. Snoj, A.; Marčeta, B.; Sušnik, S.; Melkič, E.; Meglič, V.; Dovč, P. The taxonomic status of the 'sea trout' from the north Adriatic Sea, as revealed by mitochondrial and nuclear DNA analysis. 2002, J Biogeogr, 29, 1179-1185. DOI: 10.1046/j.13652699.2002.00735.x.

59. Splendiani, A.; Ruggeri, P.; Giovannotti, M.; Caputo Barucchi, V. Role of environmental factors in the spread of domestic trout in Mediterranean streams. 2013, Freshwat Biol, 58, 2089-2101. DOI: 10.1111/fwb.12193.

60. Bianco, P.G.; Delmastro, G.B. Recenti novità tassonomiche riguardanti i pesci d'acqua dolce autoctoni in Italia e descrizione di una nuova specie di luccio. 2011, Res Wildl Conserv, 2 (suppl.), 1-14.

61. Gridelli, E. I Pesci d'Acqua Dolce della Venezia Giulia. del Bianco, D.: Udine, Italy, 1935.

62. Old Maps Online. Available online: https://www.oldmapsonline.org/ (accessed: February 2022).

63. Zanetti, M.; Nonnis Marzano, F.; Lorenzoni, M. I salmonidi italiani: linee guida per la conservazione della biodiversità. 2013, A.I.I.A.D. (Associazione Italiana Ittiologi Acque Dolci) Gruppo di Lavoro Salmonidi. Available online: http://www.aiiad.it/sito/temi/salmonidi/24-documento-salmonidi-febbraio-2013 (accessed on February 2022).

64. Lorenzoni, M. The check-list of the Italian freshwater fish fauna. 2019, Italian J Freshwat Ichthyol, 5, $239-254$.

65. Pustovrh, G.; Sušnik Bajec S.; Snoj, A. Evolutionary relationship between marble trout of the northern and the southern Adriatic basin. 2011, Mol Phylogenet Evol, 59, 761-766. DOI: 10.1016/j.ympev.2011.03.024.

66. Pustovrh, G.; Snoj, A.; Bajec, S.S. Molecular phylogeny of Salmo of the western Balkans, based upon multiple nuclear loci. 2014, Genet Sel Evol, 47, 7. DOI: 10.1186/1297-9686-46-7.

67. Lecaudey, L.A.; Schliewen, U.K.; Osinov, A.G.; Taylor, E.B.; Bernatchez, L.; Weiss, S.J. Inferring phylogenetic structure, hybridization and divergence times within Salmoninae (Teleostei: Salmonidae) using RAD-sequencing. 2018, Mol Phylogenet Evol, 124, 82-99. DOI: 10.1016/j.ympev.2018.02.022.

68. Bernatchez, L.; Guyomard, R.; Bonhomme, F. DNA sequence variation of the mitochondrial control region among geographically and morphologically remote European brown trout Salmo trutta populations. 1992, Mol Ecol, 1, 161-173. DOI: 10.1111/j.1365-294x.1992.tb00172.x.

69. Berrebi, B.; Povz, B.; Jesensek, D.; Cattaneo-Berrebi, G.; Crivelli, A.J. The genetic diversity of native, stocked and hybrid populations of marble trout in the Soca River, Slovenia. 2000, Heredity, 85, 277-287. DOI: 10.1046/j.1365-2540.2000.00753.x.

70. Bernatchez, L. The evolutionary history of brown trout (Salmo trutta L.) inferred from phylogeographic, nested clade, and mismatch analyses of mitochondrial DNA variation. 2001, Evolution, 55, 351-379. DOI: 10.1111/j.0014-3820.2001.tb01300.x.

71. Sanz, N. Phylogeographic history of brown trout: A review. In Brown Trout: Biology, Ecology and Management; Lobón-Cerviá, J.; Sanz, N., Eds.; Wiley \& Sons Ltd: Hoboken, USA, 2018; pp. 17-64.

72. Maddison, W.P. Gene trees in species trees. 1997, Syst Biol, 46(3), 523-536. DOI: 10.1093/sysbio/46.3.523.

73. Sušnik Bajec, S.; Pustovhr, G.; Jasenšek, D.; Snoj, A. Population genetic SNP analysis of marble and brown trout in a hybridization zone of the Adriatic watershed in Slovenia. 2017, Biol Conserv, 184, 239-250. DOI: 10.1016/j.biocon.2015.01.033.

74. Snoj, A.; Marić, S.; Berrebi, P.; Crivelli, A.J.; Shumka, S.; Sušnik, S. Genetic architecture of trout from Albania as revealed by mtDNA control region variation. 2009, Genet Sel Evol, 41, 22. DOI: 10.1186/1297-9686-41-22.

75. Bianco, P.G. Potential role of the paleohistory of the Mediterranean and Paratethys basins on the early dispersal of Auro-Mediterranean freshwater fishes. 1990, Ichthyol Explor Freshwat, 1, 167-184.

76. Meraner, A.; Baric, S.; Pelster, B.; Dalla Via, J. Trout (Salmo trutta) mitochondrial DNA polymorphism in the centre of the marble trout distribution area. 2007, Hydrobiologia, 579, 337-349. DOI: 10.1007/s10750-006-0479-3.

77. Pujolar, J.M.; Lucarda, A.N.; Simonato, M.; Patarnello, T. Restricted gene flow at the micro- and macro-geographical scale in marble trout based on mtDNA and microsatellite polymorphism. 2011, Front Zool, 8(7), 1-10. DOI: 10.1186/1742-9994-8-7.

78. Lucarda, A.N.; Bargelloni, L.; Patarnello, T.; Gandolfi, G. Genetic characterisation of Salmo trutta marmoratus (Cuvier, 1817) populations by means of nuclear markers: preliminary results. 1999, Quaderni ETP, 28, 1-5.

79. Meraner, A.; Baric, S.; Pelster, B.; Dalla Via, J. Microsatellite DNA data point to extensive but incomplete admixture in a marble and brown trout hybridization zone. 2010, Conserv Genet, 11, 985-998. DOI: 10.1007/s10592-009-9942-9.

80. Marazzi, S. Atlante orografico delle Alpi. SOIUSA. Suddivisione orografica internazionale unificata del Sistema Alpino. Priuli \& Verlucca, 2005.

81. Splendiani, A.; Ruggeri, P.; Giovannotti, M.; Pesaresi, S.; Occhipinti, G.; Fioravanti, T.; Lorenzoni, M.; Nisi Cerioni, P.; Caputo Barucchi, V. Alien brown trout invasion of the Italian peninsula: the role of geological, climate and anthropogenic factors. 2016, Biol Invasions, 18, 2029-2044. DOI: 10.1007/s10530-016-1149-7.

82. Splendiani, A.; Fioravanti, T.; Giovannotti, M.; Olivieri, L.; Ruggeri, P.; Nisi Cerioni, P.; Vanni, S.; Enrichetti, F.; Caputo Barucchi, V. Museum samples could help to reconstruct the original distribution of Salmo trutta complex in Italy. 2017, J Fish Biol, 90, 24432451. DOI: $10.1111 /$ jfb.13307.

83. Casalis, G. Dizionario Geografico Storico-Statistico-Commerciale degli Stati di S.M. il Re di Sardegna, Vol. 1, Maspero: Turin, Italy, 1833.

84. Casalis, G. Dizionario Storico-Statistico-Commerciale degli Stati di S.M. il Re di Sardegna, Vol. 22, Maspero: Turin, Italy, 1852.

85. Festa, E. I pesci del Piemonte. 1892, Boll Mus Zool Anat Comp Reale Univ Torino, 7(129), 1-125. 
86. Sommani, E. Il Salmo marmoratus CUV.: sua origine e distribuzione nell'Italia settentrionale. 1960, Boll Pesca, Piscicolt e Idrobiol, $15,40-47$.

87. Siebold, C.T.E. von. Ueber die Fische des Ober-Engadins. Proceedings of the meeting of the Swiss Natural Science Society in Samaden, 24th-26th Aug, 1863. 1863, Ver Schweiz Nat.forsch Ges zu Samaden; 173-190.

88. Monti, M. Notizie dei Pesci delle Provincie di Como e Sondrio e del Cantone Ticino. Franchi, C.: Como, Italy, 1864.

89. Fatio, V. Faune des Vertébrés de la Suisse. Vol. 5. Histoire Naturelle des Poissons. II part. Georg, H.: Geneva and Basel, Switzerland, 1890; pp. 354-355.

90. Schönswetter, P.; Stehlik, I.; Holderegger, R.; Tribsch, A. Molecular evidence for glacial refugia of mountain plants in the European Alps. 2005, Mol Ecol, 14, 3547-3555. DOI: 10.1111/j.1365-294X.2005.02683.x.

91. Stefani, F.; Anzani, A.; Marieni, A. Echoes from the past: a genetic trace of native brown trout in the Italian Alps. 2020, Environ Biol Fish, 102, 1327-1335. DOI: 10.1007/s10641-019-00899-y.

92. Schorr, G.; Holstein, N.; Pearman, P.B.; Guisan, A.; Kadereit, J.W. Integrating species distribution models (SDMs) and phylogeography for two species of Alpine Primula. 2012, Ecol Evol, 2(6), 1260-1277. DOI: 10.1002/ece3.100.

93. Hamilton, K.E.; Ferguson, A.; Taggart, J.B.; Tómasson, T.; Walker, A.; Fahy, E. Post-glacial colonization of brown trout, Salmo trutta L.: Ldh-5* as a phylogeographic marker locus. 1989, J Fish Biol, 35, 651-664. DOI: 10.1111/j.1095-8649.1989.tb03017.x.

94. Presa, P.; Krieg, F.; Estoup, A.; Guyomard, R. Diversité et gestion génétique de la truite commune: apport de I'étude du polymorphisme des locus protéiques et microsatellites. 1994, Gén Sél Evol, 26(Suppl. 1), 183s-202s. Available online: https://hal.archives-ouvertes.fr/hal-00894063 (accessed on February 2022).

95. Largiadèr, C.R.; Scholl, A. Effects of stocking on the genetic diversity of brown trout populations of the Adriatic and Danubian drainages in Switzerland. 1995, J Fish Biol, 47(Suppl. A), 209-255. DOI: 10.1111/j.1095-8649.1995.tb06057.x.

96. Sommani, E. Sulla presenza del Salmo fario (L.) e del Salmo marmoratus (Cuv.) nell'Italia settentrionale: loro caratteristiche ecologiche e considerazioni relative ai ripopolamenti. 1948, Boll Pesca Piscicolt Idrobiol, 3, 136-145.

97. Keller, I.; Taverna, A.; Seehausen, O. Evidence of neutral and adaptive genetic divergence between European trout populations sampled along altitudinal gradients. 2011, Mol Ecol, 20(9), 1888-1904. DOI: 10.1111/j.1365-294X.2011.05067.x.

98. Keller, I.; Schuler, J.; Bezault, E.; Seehausen, O. Parallel divergent adaptation along replicated altitudinal gradients in Alpine trout. 2012, BMC Evol Biol, 12, 210. DOI: 10.1186/1471-2148-12-210.

99. Analisi dell'opera. Natura morta con pesci di Evaristo Baschenis. Natura morta con pesci, $\sim 1670$, oil on canvas, $65 \mathrm{~cm} \times 108 \mathrm{~cm}$. Bergamo, Academy of Fine Arts in Carrara. Available online: https://www.analisidellopera.it/natura-morta-con-pesci-baschenis/ (accessed on February 2022).

100. Sacchi, B. (Platina) Platine de Honesta Voluptate et Valetudine. de Aquila, L.: Venice, Italy; 1475.

101. Giovio, P. Novocomensis de Piscibus Marinis, Lacustribus, Fluviatilibus, item de Testaceis ac Salsamentis Liber. Minitii Calvi, F.: Rome, Italy; 1527.

102. Salviani, I. Aquatilium Animalium Historiae, Liber Primus: cum Eorumdem Formis, Aere Excusis. Saluianum, H.: Rome, Italy; 1554.

103. Porcacchi, T.; Giolito de Ferrari, G.; Gesuiti: Collegio, R. La Nobiltà della Città di Como Descritta da Thomaso Porcacchi da Castiglione Arretino. Con la tavola delle cose notabili. Giolito G., di Ferrarii: Venice, Italy; 1569.

104. Scappi, B. Opera di Bartolomeo Scappi, Mastro dell'arte del Cucinare, Divisa in Sei Libri. de' Vecchi, A.: Venice, Italy; 1570.

105. Grattarolo, B. Historia della Riviera di Salò. Sabbio, V.: Brescia, Italy; 1599.

106. Stefani, B. L'arte di Ben Cucinare, et Instruire i Men Periti in Questa Lodevole Professione: Dove Anco s'Insegna a Far Pasticci, Sapori, Salse, Gelatine, Torte, et Altro. Osanna, Mantua, Italy; 1662.

107. Roberti, G. Lettera Sopra il Canto de' Pesci. della Volpe, L.: Bologna, Italy; 1767.

108. Delling, B. Morphological distinction of the marble trout, Salmo marmoratus, in comparison to marbled Salmo trutta from River Otra, Norway. 2002, Cybium, 26, 283-300. DOI: /10.26028/cybium/2002-264-004.

109. Snoj, A.; Glamuzina, B.; Razpet, A.; Zablocki, J.; Bogut, I.; Lerceteau-Köhler, E.; Pojskić, N.; Sušnik, S. Resolving taxonomic uncertainties using molecular systematics: Salmo dentex and the Balkan trout community. 2010, Hydrobiologia, 651, 199-212. DOI: 10.1007/s10750-010-0297-5.

110. Pontalti, L. La trota marmorata dai fiumi ai ruscelli: possibilità, per una specie in pericolo, di allungare il proprio habitat. Seconda parte: acclimatamento di una popolazione. 2020, Dendronatura, 1: 76-83.

111. Huitfeldt-Kaas, H. Ferskvandsfiskenes Utbredelse og Indvandring i Norge. Central Trykkeriet: Oslo, Norway; 1918.

112. Sønstebø, J.H.; Borgstrøm, R.; Heun, M. Genetic structure of brown trout (Salmo trutta L.) from the Hardangervidda mountain plateau (Norway) analyzed by microsatellite DNA: A basis for conservation guidelines. 2007, Conserv Genet, 8, 33-44. DOI: 10.1007/s10592-006-9145-6.

113. Miró, A.; Ventura, M. Evidence of exotic trout mediated minnow invasion in Pyrenean high mountain lakes. 2015, Biol Invasions, 17, 791-803. DOI: 10.1007/s10530-014-0769-z.

114. Tiberti, R.; Splendiani, A. Management of a highly unlikely native fish: The case of arctic charr Salvelinus alpinus from the Southern Alps. 2019, Aquat Conserv: Mar Freshwat Ecosyst, 29(2), 312-320. DOI: 10.1002/aqc.3027.

115. Vilizzi, L. The common carp, Cyprinus carpio, in the Mediterranean region: origin, distribution, economic benefits, impacts and management. 2011, Fisheries Manag Ecol, 19(2), 93-110. DOI: 10.1111/j.1365-2400.2011.00823.x.

116. Todesco, M.; Pascual, M.A.; Owens, G.L.; Ostevik, K.; Moyers, B.T.; Hubner, S.; Heredia, S.M.; Hahn, M.A.; Caseys, C.; Bock, D.G.; Rieseberg, L.H. Hybridization and extinction. 2016, Evol Appl, 9(7), 892-908. DOI: 10.1111/eva.12367. 
117. Meldgaard, T.; Crivelli, A.J.; Jesensek, D.; Poizat, G.; Rubin, J.-F.; Berrebi, P. Hybridization mechanisms between the endangered marble trout (Salmo marmoratus) and the brown trout (Salmo trutta) as revealed by in-stream experiments. 2007, Biol Conserv, 136(4), 602-611. DOI: 10.1016/j.biocon.2007.01.004.

118. Merati, F.; Pascale, M.; Perosino, G.C. Storia della trota mediterranea in Piemonte. 2021, Cent Ric Ecol Sci Territ (CREST). Available online: https://green-crest.blog/area-tecnico-scientifica/ (accessed on February 2022).

119. Lucarda, A.N.; Patarnello, T.; Forneris, G.; Pascale, M. Population genetics of S. trutta marmoratus, S. trutta trutta and their hybrid of the Pellice River basin (Piemonte, Italy). 2000, Quaderni ETP, 29, 13-21.

120. McDonald, D.B.; Parchman, T.L.; Bower, M.R.; Hubert, W.A.; Rahel, F.J. An introduced and a native vertebrate hybridize to form a genetic bridge to a second native species. 2008, Proc Nat Acad Sci, 105(31), 10837-10842. DOI: 10.1073/pnas.0712002105.

121. Aprahamian, M.W.; Smith, K.M.; McGinnity, P.; McKelvey, S.; Taylor, J. Restocking of salmonids-opportunities and limitations. 2003, Fisheries Res, 62, 211-227. DOI: 10.1016/S0165-7836(02)00163-7.

122. Arlinghaus, R.; Lorenzen, K.; Johnson, B.M.; Cooke, S.J.; Cowx, I.G. Management of freshwater fisheries: addressing habitat, people and fishes. In Freshwater Fisheries Ecology; Craig, J.F., Ed.; Wiley \& Blackwell: Oxford, UK, 2015; pp. 557-579. DOI: 10.1002/9781118394380.

123. Jellyman, P.G.; McHugh, P.A.; Simon, K.S.; Thompson, R.M.; McIntosh A.R. The effects of brown trout on the trophic webs of New Zealand streams. In Brown Trout: Biology, Ecology and Management; Lobón-Cerviá, J.; Sanz, N., Eds.; Wiley: Hoboken, USA, 2018; pp. 569-598.

124. Schöffmann, J.; Marić, S.; Snoj, A. Trout of Southeast Europe, Western and Central Asia. In Trout and Char of the World; Kershner, J.L.; Williams, J.E.; Gresswell, R.E.; Lobón-Cerviá, J., Eds.; American Fisheries Society: Bethesda, USA, 2019, pp. 411-456.

125. Tiberti, R.; Brighenti, S. Do alpine macroinvertebrates recover differently in lakes and rivers after alien fish eradication? 2019, Knowl Manag Aquat Ecosyst, 420, 37. DOI: 10.1051/kmae/2019029.

126. Zarco, A.; Corbalán, V.; Debandi, G. Predation by invasive rainbow trout on the critically endangered Pehuenche spiny-chest frog. 2020, J Fish Biol, 98(3), 878-880. DOI: 10.1111/jfb.14609.

127. Moritz, C. Defining 'evolutionary significant units' for conservation. 1994, Trends Ecol Evol, 9, 373-375. DOI: 10.1016/01695347(94)90057-4.

128. Almodóvar, A.; Nicola, G.G.; Elvira, B.; García-Marín, J.L. Introgression variability among Iberian brown trout evolutionary significant units: the influence of local management and environmental features. 2006, Freshwat Biol, 51, 1175-1187. DOI: 10.1111/j.1365-2427.2006.01556.x.

129. Budy, P.; Rogers, K.B.; Kanno, Y.; Penaluna, B.E.; Hitt, N.P.; Thiede, G.P.; Dunham, J.; Mellison, C.; Somer, W.L.; DeRito, J. Distribution and status of trout and char in North America. In Trout and Char of the World; Kershner, J.L.; Williams, J.E.; Gresswell, R.E.; Lobón-Cerviá, J., Eds.; American Fisheries Society: Bethesda, USA, 2019; pp. 193-250.

130. Splendiani, A.; Fioravanti, T.; Giovannotti, M.; Negri, A.; Ruggeri, P.; Olivieri, L.; Nisi Cerioni, P.; Lorenzoni, M.; Caputo Barucchi, V. The effects of paleoclimatic events on Mediterranean trout: preliminary evidences from ancient DNA. 2016, PLoS ONE, 11(6), e0157975. DOI: 10.1371/journal.pone.0157975.

131. Kuwae, M.; Tamai, H.; Doi, H.; Sakata, M.K.; Minamoto, T.; Suzuki, Y. Sedimentary DNA tracks decadal-centennial changes in fish abundance. 2020, Commun Biol, 3, 558. doi:10.1038/s42003-020-01282-9.

132. Gary, M.K.; Nielsen, L.A.; Knight, R.L.; Schenborn, D.A. Ecosystem Management. Adaptive, Community-Based Conservation; Island Press, Washington, USA; 2002. 